\title{
Att utveckla elevers förmåga att formulera undersökningsbara frågor i naturvetenskap: Mangling av en didaktisk modell
}

Sara Planting-Bergloo 1,2, Maria Andrée ${ }^{1}$, Josefin Reimark², Emma Henriksson ${ }^{1}$, Sebastian Björnhammer ${ }^{1,3}$, Cecilia Dudas ${ }^{1,2}$, Per-Olof Freerks ${ }^{2}$, Sofija Jahdadic ${ }^{2}$, Malin Lavett Lagerström ${ }^{1,2}$, Johanna Lundström ${ }^{4,5}$, Johanna da Luz ${ }^{2}$, Johan Nordling ${ }^{2}$, Sara Puck ${ }^{4}$, Per Wennerström², Fredrik Westman² och Jonna Wiblom $^{1,2}$

${ }^{1}$ Stockholms universitet, Sverige

${ }^{2}$ Stockholms stad, Sverige

${ }^{3}$ Kunskapsskolan, Sverige

${ }^{4}$ Värmdö kommun, Sverige

${ }^{5}$ Nacka kommun, Sverige

En viktig målsättning för naturvetenskaplig undervisning är att utveckla förmågan att formulera undersökningsbara frågor. Syftet med den här studien är att undersöka hur undervisning som utformats med hjälp av metoden Question Formulation Technique (QFT) kan stödja utveckling av elevers förmåga att formulera naturvetenskapligt undersökningsbara frågor. QFT är en modell för att utveckla elevers förmåga att formulera och värdera sina egna frågor i allmänhet. I studien prövas QFT i en svensk skolkontext och inom ramen för naturvetenskaplig undervisning. Studien genomfördes som en interventionsstudie i gymnasieskolan och inom ramen för kursen Gymnasiearbete. I kursen ska eleverna genomföra en egen naturvetenskaplig undersökning. QFT användes för att utforma undervisning som del av introduktionen till kursen. Data består av videoinspelningar av elevsamtal från undervisning som har analyserats utifrån ett pragmatiskt ramverk med organiserande syften och praktisk epistemologisk analys. Resultaten visar vilka närliggande syften som etableras i elevernas samtal om undersökningsbara frågor i undervisningen: (A) att producera så många frågor som möjligt, (B) att bedöma vilka frågor som är mest relevanta, (C) att kategorisera frågor, (D) att hitta och specificera ett undersökningsobjekt och (E) att planera för att genomföra en undersökning. Slutsatsen är att QFT kan fungera som stöd för lärares planering av undervisning om naturvetenskapligt undersökningsbara frågor under förutsättning att läraren aktivt stödjer eleverna i att uppmärksamma centrala kvaliteter avseende undersökningsbarhet och genom att binda samman närliggande syften med det övergripande syftet.

Nyckelord: Systematiskt undersökande, undersökningsbara frågor, Question Formulation Technique (QFT), didaktisk modellering, gymnasiearbete 
Att utveckla elevernas förmåga att genomföra systematiska undersökningar är en viktig del av naturvetenskaplig undervisning på alla nivåer (Hodson, 2014; Hofstein \& Lunetta, 2004). I de svenska styrdokumenten för gymnasieskolan (Skolverket, 2011a) ges naturvetenskapliga arbetsmetoder en framträdande plats och målen för undervisning i ämnena kemi, biologi och fysik innefattar specifikt "naturvetenskapliga arbetsmetoder som att formulera och söka svar på frågor" (Skolverket, 2011a). Förmågan att genomföra systematiska undersökningar innefattar hela den undersökande processen: från att formulera undersökningsbara frågor och välja undersökningsmetoder, till att hantera material och utrustning, värdera resultat och slutligen formulera och redovisa slutsatser. I den här artikeln fokuserar vi specifikt på förmågan att formulera undersökningsbara frågor i naturvetenskap.

\section{Tidigare forskning om formulering av undersökningsbara frågor i naturvetenskap}

I ett internationellt perspektiv är forskningen om laborationer och undersökande arbete i naturvetenskaplig undervisning mycket omfattande (för en forskningssammanställning av laborationer i naturvetenskaplig undervisning se Skolforskningsinstitutet, 2020). Laborationer och undersökande arbetssätt kan svara mot olika mål i undervisningen. Det kan handla om att eleverna ska lära sig att göra naturvetenskapliga undersökningar (doing science), att lära sig om vad som kännetecknar naturvetenskapliga arbetssätt och naturvetenskapens karaktär (learning about science) samt att lära sig naturvetenskapliga begrepp, teorier och modeller (learning science) (Gyllenpalm, 2010; Hodson, 2014). Tidigare forskning visar att de olika målen med laborativt arbete som undervisningsmetod och som innehåll tenderar att sammanblandas (Abrahams \& Millar, 2008; Gyllenpalm, Wickman, \& Holmgren, 2010; Hodson, 1996). Lederman (2007) pekar också på att målen setts som olika viktiga. Oftast har målen om att eleverna ska lära sig göra naturvetenskapliga undersökningar, lära sig om naturvetenskapliga arbetssätt och naturvetenskapens karaktär betraktats som mindre viktiga än att eleverna ska lära sig naturvetenskapliga begrepp. Detta gäller även svenska lärare som enligt Högström, Ottander och Benckert (2012) oftast använder laborativa arbetssätt som en metod för att utveckla elevernas förståelse för naturvetenskapliga begrepp och fenomen. 
Utrymme för elever att formulera vilka frågor som ska undersökas ges inom den slags undersökande uppgifter som kallas öppna undersökningar. Wolf och Fraser (2008) skiljer på öppna och bekräftande undersökningar (inquiry och non-inquiry laboratory teaching). I öppna undersökningar kan elever ges möjlighet att ställa egna undersökningsfrågor, välja metod och sätt att sammanställa resultaten från undersökningarna. I en bekräftande laboration styrs däremot såväl frågor som metod och sätt att tolka data av läraren. Principiellt sett kan både öppna och bekräftande undersökningar svara mot de olika målen med laborativt undersökande arbetssätt även om det i praktiken bara är i de allra öppnaste formerna av undersökande arbete som elever brukar uppmuntras till att formulera egna frågor (Bianchi \& Bell, 2008; Stokhof m.fl., 2019). För att utveckla elevernas förmåga till systematiskt undersökande och mer specifikt förmågan att formulera undersökningsbara frågor krävs dock ett systematiskt arbete med just formulering och bearbetning av frågor.

Tidigare forskning har visat att lärare sällan låter elever formulera egna undersökningsbara frågor utifrån en övergripande forskningsfråga eller problemsituation. Enligt en svensk studie av Lunde, Rundgren och Chang Rundgren (2015), som undersökte lärares strategier för att involvera elever i naturvetenskapligt undersökande arbete, gav lärarna återkommande uttryck för att det var svårt att planera aktiviteter som kunde ge eleverna större inflytande över de undersökande aktiviteterna än traditionellt styrda laborationer. En strategi som lärarna använde var att "öppna upp” styrda laborationer som de tidigare använt i undervisningen. En annan strategi var att imitera uppgifter i de nationella proven med fokus på systematiskt undersökande. Anpassningen av laborationerna innefattade att lärarna formulerade om styrda laborationer för att skapa större utrymme för eleverna att planera, genomföra och utvärdera dem. Vid imitation av uppgifter i de nationella proven gav lärarna varje elev en undersökningsfråga som eleven sedan fick göra en planering till. I studien saknas dock helt exempel på laborationer där eleverna kunde få möjlighet att formulera egna forskningsfrågor. Den risk som Lunde m.fl. (2015) pekar på är att naturvetenskapligt undersökande framställs som en sluten process som leder mot givna sanningar.

Observationerna i Lunde med fleras studie (2015) är i linje med resultaten från Rothstein och Santanas (2011) studie som visar att undervisning i USA sällan behandlar konsten att ställa egna frågor. Att ställa frågor ses snarare som något som tillhör lärarens domän. Lärare lägger ofta mycket tid på att formulera och bearbeta frågor i syfte att engagera och väcka diskussion och nyfikenhet. I naturvetenskaplig 
undervisning finns det också en risk att det uppstår konkurrens mellan undervisning om ämneskunskaper och målet om att eleverna ska utveckla en förståelse för systematiskt undersökande. Detta innebär att undervisning för att utveckla förmågan att formulera frågor ofta prioriteras bort (Rothstein, Santana \& Minigan, 2015). Rothstein och Santana (2011) menar dessutom att många elever upplever uppgiften att formulera frågor som utmanande och att frågeformulering i helklass kan upplevas hämmande.

Bielik och Yarden (2016) visar, i en fallstudie av en spetsutbildning med inriktning bioteknik, att undervisning med syfte att utveckla elevers förmåga att formulera undersökningsbara frågor behöver kännetecknas av elevcentrering, dialog och nära interaktion mellan lärare och elever. För att utveckla elevers förmåga att formulera frågor som utgångspunkt för naturvetenskapligt undersökande krävs ett målmedvetet och noggrant arbete av lärare. Undervisningen behöver arrangeras så att eleverna både kan få generera och bearbeta sina egna frågor. Möjligheter för eleverna att arbeta med formulering av egna frågor kan också ha potential att bidra till att göra eleverna mer engagerade i det systematiskt undersökande då de känner att de får "äga" vad undersökandet riktas mot (Andrée \& Lager-Nyqvist, 2012; Andrée, 2012; Chaiklin, 1999; Eriksson m.fl., 2018; Kelly \& Cunningham, 2019; Rothstein \& Santana, 2011). Den tidigare forskningen är dock inte entydig. Wolf och Fraser (2008) rapporterar att de inte ser några skillnader i kunskapsprov mellan de elever som hade fått arbeta med öppna och bekräftande undersökningar och de som inte gjort det, även om de elever som hade fått göra öppna undersökningar formulerade sig mer positivt om undervisningen.

I den här studien undersöker vi om och i så fall hur en metod som kallas Question Formulation Technique (QFT) skulle kunna användas för att stödja elevers förmåga att formulera naturvetenskapligt undersökningsbara frågor. Metoden, som utvecklats av Dan Rothstein och hans kollegor (Rothstein et al., 2015; Rothstein \& Santana, 2011), kan beskrivas som elevcentrerad eftersom den fokuserar på elevers formulering och bearbetning av frågor i dialog med varandra. Metoden går i korthet ut på att eleverna på ett strukturerat sätt formulerar och bearbetar frågor i relation till ett eller flera påståenden. En huvudsaklig anledning till vårt val att ta utgångspunkt i QFT i den här studie är att QFT utgör en modell som prövats vetenskapligt i en lång rad sammanhang (både i och utanför undervisning). Metoden eller modellen har som syfte just att utveckla människors förmåga att formulera frågor kring olika temata. QFT har dock inte prövats vetenskapligt i en svensk eller nordisk kontext och inte 
heller i relation till undervisningssyftet att utveckla elevers förståelse för systematiskt undersökande i skolans naturvetenskapliga ämnen.

\section{Question Formulation technique, QFT, som didaktisk modell}

QFT är en metod för att lära elever, oavsett utbildningsnivå, att formulera bättre frågor (Rothstein et al., 2015; Rothstein \& Santana, 2011). QFT har utvecklats och prövats i en mängd olika amerikanska undervisningssammanhang från förskola till universitet och inom så vitt skilda ämnesområden som afrikansk historia, geometri och plattektonik (Rothstein \& Santana, 2011). QFT har använts både för att introducera elever till nya undervisningsmoment och för att utvärdera elevers kunskaper (Rothstein \& Santana, 2011). Tidigare forskning om användning av QFT visar att eleverna tenderar att bli mer delaktiga i undervisningen, utvecklar större grad av ägandeskap (Minigan m.fl., 2017; Rothstein, Santana, \& Minigan, 2011) och nyfikenhet inför det innehåll som behandlas i undervisningen (Clark m.fl., 2019). QFT har också prövats som metod för att utveckla aktörskap utanför skolan, exempelvis hos patienter inom hälsovård i USA (Deen m.fl., 2011). Det finns dock inga tidigare publicerade studier där QFT prövats som utgångspunkt för systematiskt undersökande inom naturvetenskaplig didaktisk forskning, inte heller av QFT i en svensk skolkontext.

Undervisning som är utformad utifrån QFT följer nedanstående modell, enligt Rothstein och Santana (2011), med följande sex delsteg:

1. Läraren presenterar ett frågeområde. Syftet är att fånga elevernas uppmärksamhet och att stimulera själva frågeformulerandet. Exempel på frågeområden kan vara påståenden, fraser eller visuella resurser. Ett frågeområde bör dock inte ges i form av en eller flera frågor.

2. Eleverna uppmanas att individuellt producera så många frågor som möjligt till det givna frågeområdet. Frågorna ska antecknas exakt som de först formulerades och eventuella påståenden ska göras om till frågor. Frågorna ska i den här delen av processen inte värderas, diskuteras, bedömas eller besvaras.

3. Eleverna arbetar tillsammans med att bearbeta och förbättra sina frågor. Bland annat identifierar, jämför och analyserar eleverna öppna och slutna frågor och omformulerar öppna frågor till slutna och vice versa. I processen med att bearbeta och förbättra frågorna handleder även läraren eleverna i diskussioner om fördelar- och nackdelar med respektive frågetyp. 
4. Läraren tillhandahåller kriterier för hur eleverna ska rangordna eller prioritera de bearbetade frågorna. Det kan exempelvis innebära att eleverna väljer ut tre frågor utifrån vad de vill undersöka vidare.

5. Lärare och elever bestämmer tillsammans hur frågorna ska användas.

6. QFT avslutas med en gemensam utvärdering. Genom att tillsammans synliggöra hur eleverna producerat, förbättrat och prioriterat sina frågor skapas möjligheten att tillämpa kunskaperna i nya sammanhang.

Det övergripande syftet med studien är att pröva QFT som en didaktisk modell. Mer specifikt om och hur QFT fungerar som ett verktyg för undervisning som syftar till att utveckla elevernas förmåga att formulera undersökningsbara frågor i naturvetenskap (jmf Dudas m.fl., 2018; Lunde \& Sjöström, 2020; Seifeddine Ehdwall, \& Wickman, 2018). Enligt Wickman, Hamza och Lundegård (2018) är en didaktisk modell utformad för specifika syften, användare och användningsområden. Didaktiska modeller är med andra ord sällan generiska utan riktar sig mot olika grupper av lärare och/eller elever. Didaktiska modellers överförbarhet och relevans kan dock prövas genom mangling. Manglingen innebär att en modell skapad utifrån analys av situerade undervisningssituationer prövas i nya undervisningssammanhang. En mangling är alltså en kritisk prövning med syfte att skapa insikter om modellens begränsningar och ge möjligheter till en vidareutveckling av modellen (Wickman, Hamza, \& Lundegård, 2018). QFT har dock utvecklats med anspråk på att vara en generell modell som kan användas såväl i som utanför skolan.

\section{En pragmatisk utgångspunkt}

Studien tar sin teoretiska utgångspunkt i ett pragmatiskt perspektiv på undervisning och lärande där kunskap ses som förankrad i sociala och kulturella praktiker. Enligt ett pragmatiskt perspektiv på lärande sker allt meningsskapande genom interaktion med andra människor och omgivningen. Det innebär att lärande är situerat. Centrala begrepp inom pragmatismen är erfarenhet och syften (Dewey, 1938/2015). Erfarenhet skapas i transaktion med omgivningen och är aldrig enbart individuell. Erfarenhet karakteriseras av två grundläggande principer: kontinuitet och interaktion. Kontinuitet innebär att tidigare erfarenheter transformeras i nya sammanhang. I undervisning kan det innebära att elevens tidigare unika erfarenheter samverkar och omvandlas i en undervisningskontext. Kontinuitet i handling innebär 
att det som eleven lärt sig i en undervisningssituation hjälper denne att förstå och handskas med kommande situationer (Wickman, 2006; 2014). Begreppet interaktion beskriver omgivningens samspel med elevens behov, syften, önskningar och möjligheter. Det möjliggör i sin tur konstruktioner av nya erfarenheter. Interaktionsbegreppet belyser därmed behovet av att läraren arbetar med att binda samman elevernas förmågor, behov och tidigare erfarenheter med undervisningens syften (Dewey, 1938/2015). Utifrån ett pragmatiskt perspektiv väcks frågor kring om och hur QFT kan fungera som redskap för lärare i att stötta elevers utveckling av förmågan att formulera naturvetenskapligt undersökningsbara frågor. Med andra ord undersöks i vilka avseenden QFT kan bidra till att elevernas tidigare erfarenheter av olika naturvetenskapliga fenomen och laborativt arbete aktualiseras, rekonstrueras och transformeras i relation till formulering av naturvetenskapligt undersökningsbara frågor.

Den här studien fokuserar specifikt på hur kontinuitet etableras mellan elevernas arbete med att utveckla frågor genom undervisning som planerats med stöd av QFT och undervisningens syfte att utveckla elevernas förmåga att formulera naturvetenskapligt undersökningsbara frågor. I ett pragmatiskt perspektiv kallas de syften som etableras i elevernas samtal för närliggande syften och de syften som avser det lärande som undervisningen bör leda fram till för övergripande syften. Tillsammans benämns de olika syftena för organiserande syften (Johansson \& Wickman, 2011). Det övergripande syftet kan exempelvis vara kursplanens syfte eller de syften som läraren formulerar för en lektion. Det övergripande syftet behöver inte vara klart för eleverna från början. I den här studien var undervisningens övergripande syfte att eleverna skulle utveckla förmågan att formulera naturvetenskapligt undersökningsbara frågor. De närliggande syftena etablerades i elevernas samtal. Johansson och Wickman (2011) menar att möjligheter till meningsskapande skapas när det närliggande och det övergripande syftet blir kontinuerliga med varandra. På så sätt kan en kontinuitet mellan tidigare och nuvarande undervisningssammanhang, både vad gäller naturvetenskapligt innehåll och systematiskt undersökande, etableras (jfr Andrée, Wickman \& Lager-Nyqvist, 2017). I planeringen av en lektion kan läraren planera för vissa närliggande syften men huruvida det närliggande syftet blir kontinuerligt med undervisningens övergripande syfte är en empirisk fråga. Det handlar om vilka syften som etableras i de samtal som tar form i undervisningen. I interaktion mellan lärarens instruktioner och elevernas erfarenheter, intressen och behov kan elevernas samtal ta vägar som 
leder bort från undervisningens planerade övergripande syften. Eleverna kan alltså skapa mening genom arbete med uppgiften och de olika stegen i QFT, även på andra sätt än de avsedda. Huruvida lärarens och elevernas syften blir kontinuerliga blir därmed en viktig del i analysen och något som synliggörs med hjälp av de organiserande syftena.

\section{Syfte och forskningsfråga}

Syftet med den här studien är att undersöka hur undervisning som utformats med hjälp av QFT kan stödja utveckling av elevers förmåga att formulera naturvetenskapligt undersökningsbara frågor. Målet med studien är att mangla QFT som didaktisk modell i en svensk undervisningskontext och på så vis bidra till utveckling av undervisning som kan stödja utvecklingen av förmågan till systematiskt undersökande.

Då studien utgår från en pragmatisk syn på lärande handlar syftet om i vilka avseenden QFT kan bidra till att skapa kontinuitet mellan de närliggande syften som etableras i undervisningen och det övergripande syftet om naturvetenskaplig undersökningsbarhet. Den forskningsfråga som fokuseras är: Vilka närliggande syften etableras $i$ elevernas arbete med att formulera undersökningsbara frågor $i$ naturvetenskap, i undervisning som utformats utifrån QFT?

\section{Metod}

Studien ingår i ett större design-baserat projekt som genomförts inom ramen för Stockholm Teaching \& Learning Studies ${ }^{1}$. Design-baserad forskning kännetecknas av ett arbete med interventioner där sätt att utforma undervisning designas, prövas och analyseras i cykler i verkliga klassrum (McKenney \& Reeves, 2012; The Design-Based Research Collective, 2003). Den design-baserade forskningsansatsen syftar till samtidig utveckling av sätt att designa undervisning och sätt att förstå undervisning - teori om undervisning. Projektet bygger på ett samarbete mellan lärare och forskare som tillsammans utgjorde en forskargrupp. Projektet omfattar totalt 222 elever, nio lärare, sex forskare och en lärarstudent som genomförde en verksamhetsförlagd del av sin grundläggande lärarutbildning med en av de deltagande lärarna som handledare. Alla forskare har en bakgrund som antingen högstadie- eller

\footnotetext{
${ }^{1}$ STLS är en plattform för undervisningsutvecklande forskning i samverkan mellan lärare och forskare i stockholmsregionen.
} 
gymnasielärare i naturvetenskapliga ämnen och lärarna undervisade i naturvetenskapliga ämnen på gymnasiet. Några av lärarna har dessutom bakgrund som forskare i naturvetenskapliga ämnen. Projektet genomfördes med interventioner i tre cykler på tre olika gymnasieskolor under två år. De data som genererats genom interventionerna i form av elevsamtal har analyserats och redovisats i en annan studie med fokus på vad som kännetecknar gymnasieelevers förmåga att formulera undersökningsbara frågor i naturvetenskap (Björnhammer m.fl., 2020). I den här studien görs en näranalys av den första interventionen (som genomfördes under den första cykeln på en av de tre skolorna) där QFT användes som utgångspunkt för design av undervisningen.

\section{Planering och genomförande av undervisning utifrån QFT}

Då två av de deltagande lärarna skulle starta upp kursen Gymnasiearbete bestämdes att QFT skulle prövas i relation till just den kursen. I interventionen deltog två klasser med tredjeårselever som just skulle påbörja sitt gymnasiearbete. Kursen Gymnasiearbete ingår i alla gymnasieprogram, men är relaterad till examensmålen för respektive nationellt gymnasieprogram och syftar till att visa att eleven är förberedd för yrkesutövning eller fortsatta studier. Vad gäller gymnasiearbetet för det naturvetenskapliga programmet ska det "utföras på ett sådant sätt att eleven formulerar en frågeställning samt planerar, genomför och utvärderar ett större arbete som utgår från centrala kunskapsområden inom programmet” (Skolverket, 2011b, s. 248).

Inför elevernas kursstart arbetade forskningsgruppen med att anpassa QFT så att den skulle kunna fungera som en introduktion till gymnasiearbetet. Flera av de lärare som ingick i forskargruppen hade undervisat eleverna $i$ flera andra naturvetenskapliga kurser och hade därför kunskap om elevgrupperna. Förutom en kort genomgång av de olika delsteg som utgör QFT presenterade lärarna även tre olika frågeområden för eleverna (steg 1 i QFT). De aktuella frågeområdena var "Ipren och Alvedon har olika maxdosering per dygn" (kemi), "Honung innehåller antibakteriella ämnen" (biologi) och ”Det finns LED- och halogenlampor" (fysik). Utgångspunkt för forskargruppens val av frågeområden var att gymnasiearbetet ska ta sin utgångspunkt i centrala kunskapsområden för respektive gymnasieprogram. Därför valdes ett frågeområde för vart och ett av skolämnena kemi, biologi och fysik. Som steg 2 instruerades eleverna att individuellt formulera minst tjugo frågor utifrån ett eller 
flera av de givna frågeområdena. De individuella frågorna skulle formuleras förutsättningslöst, i snabb följd och inte bearbetas. Det tredje steget, med huvudsyftet att frågorna skulle bearbetas och förbättras, genomfördes parvis. Uppgiften att bearbeta frågorna innefattade att eleverna skulle kategorisera frågorna, resonera kring fördelar och nackdelar med varje frågetyp, ändra en öppen fråga till en sluten och vice versa, fundera över om frågan innehåller oberoende/beroende/kontrollvariabler och samtala om för vem frågorna har relevans. Delsteget innebar att eleverna även skulle försöka omformulera frågorna. Då tredjeårseleverna redan läst många av de grundläggande naturvetenskapliga gymnasiekurserna så beskrev introduktionen till delsteget inte begrepp som variabler eller öppna/slutna frågor närmare, utan eleverna förutsattes vara väl förtrogna med begreppen. Efter att eleverna på olika sätt bearbetat frågorna så introducerades delsteg 4, som innebar att eleverna skulle rangordna och prioritera frågorna utifrån undersökningsbarhet och relevans. Eleverna, som i detta steg arbetade i grupper om fyra, skulle också försöka att motivera sina val och välja tre frågor att arbeta vidare med. I steg 5 ombads eleverna att skissa på en design av en naturvetenskaplig undersökning med utgångspunkt i någon av de tre frågor de valt i det föregående delsteget. Att skissera en undersökning var en övningsuppgift inför det kommande gymnasiearbetetsprojektet och det ingick alltså inte i uppgiften att genomföra den skisserade undersökningen praktiskt. Det sjätte och sista steget var en gemensam utvärdering. I detta steg fick eleverna reflektera i helkass över de frågor som de formulerat och bearbetat i relation till design och genomförande av en praktisk undersökning. Då elevernas egenformulerade frågor eller designer av undersökningar inte utgör studiens forskningsobjekt finns de inte redovisade i samband med att studiens resultat presenteras. I studiens resultatdel analyseras istället elevernas samtal om att formulera naturvetenskapligt undersökningsbara frågor.

Sammanfattningsvis syftade den genomförda lektionen till att ge en introduktion till och inspiration inför det egna projekt som eleverna skulle genomföra inom kursen Gymnasiearbete. Efter introduktionen som planerats utifrån QFT gavs eleverna, under samma lektion, även tid till att formulera frågor utifrån egna intresseområden. I gymnasiearbetets fortsatta undervisning delades eleverna in i ämnesgrupper för att handledas av en lärare med kompetens inom det valda naturvetenskapliga området. Denna process ligger dock utanför den här studien. 


\section{Datainsamling}

I den intervention som ligger till grund för den här studien ingick två klasser med 32 elever vardera. Två av lärarna i forskningsgruppen ansvarade för en lektion om 130 minuter i varsin klass. De båda lektionerna videofilmades i sin helhet och vid gruppdiskussionerna riktades videokameror mot eleverna. Då eleverna både arbetade individuellt, i par och i grupper om fyra är det dock svårt att redogöra för hur många elevgrupper som dokumenterades. Forskningsgruppen arbetade sedan gemensamt med att transkribera hela det inspelade materialet.

\section{Dataanalys}

Data har analyserats med hjälp av praktisk epistemologisk analys, PEA. PEA är en metod för att analysera meningsskapande i klassrummet som utvecklats utifrån ett pragmatiskt ramverk (Wickman \& Östman, 2002). PEA synliggör lärande som process, det vill säga hur deltagande och interaktion medieras genom språk och artefakter, och blir därmed ett sätt att försöka förstå sambandet mellan vad eleverna gör och säger i relation till lärande. En PEA utgår ifrån de analytiska begreppen: syften, stå fast, relation, möten och mellanrum (Wickman \& Östman, 2002). I en undervisningsaktivitet sker möten mellan elever, deras tidigare och nya erfarenheter och omgivningen. Det är också så att viss språkanvändning och handling står fast. Att något står fast innebär att det finns en gemensam förståelse, en gemensam utgångspunkt för eleverna och att de inte behöver utforska detta vidare. Möten kan också skapa mellanrum, vilket betyder att något i situationen är oklart. När mellanrummet sedan fylls rekonstrueras och transformeras tidigare erfarenheter till nya i relation till det som i aktiviteten står fast. Det kan också vara så att ett mellanrum inte fylls utan istället dröjer kvar (Wickman, 2006; Wickman \& Östman, 2002).

De elevsamtal som dokumenterades under elevernas arbete med QFT analyserades enligt följande: Vid genomläsning av transkripten identifierades fem närliggande syften i elevernas samtal. I det fortsatta analysarbetet förhandlades och bearbetades sedan de närliggande syftena av flera av forskargruppens deltagare. Det gemensamma arbetet kan ses som en form av validering där olika tolkningar prövas (Bryman, 2011). Därefter har en näranalys genomförts med hjälp av praktisk epistemologisk analys, PEA (Wickman \& Östman, 2002). De fem närliggande syftena exemplifieras med excerpt i resultatdelen. Dessa har valts för att så tydligt som möjligt illustrera de identifierade närliggande syftena. 


\section{Etiska överväganden}

De elever och lärare som på olika sätt varit involverade i studien har informerats muntligt och skriftligt i enlighet med de forskningsetiska principerna om informationskravet, samtyckeskravet, konfidentialitetskravet och nyttjandekravet (Vetenskapsrådet, 2017). Samtliga elever är över 15 år och har även gett sitt skriftliga samtycke till att delta i studien. Av konfidentialitetsskäl anges deltagarna med pseudonymer i de excerpt som redovisas. Även skolans namn har avlägsnats. Transkribering och analys av elevernas samtal har skett efter kursens slut då de deltagande eleverna fătt betyg på kursen Gymnasiearbete och därmed avslutat sina gymnasiestudier.

\section{Resultat}

Med hjälp av organiserande syften identifierades fem närliggande syften i elevernas samtal. De närliggande syften som identifierats är inte direkt relaterade till de olika stegen i QFT även om analysen visar att eleverna i sina samtal har stöd av den struktur som användningen av QFT innebär. De närliggande syften som identifierades var:
A. Att producera så många frågor som möjligt
B. Att bedöma vilka frågor som är mest relevanta
C. Att kategorisera frågor
D. Att hitta och specificera ett undersökningsobjekt
E. Att planera för att genomföra en undersökning

I studien är det framförallt elevernas samtal som är i fokus och lärarens röst återfinns därför inte i excerpten från samtalen. Lärarna är dock hela tiden närvarande i undervisningen och strukturerar och leder elevernas arbete i linje med planeringen.

\section{A. Att producera så många frågor som möjligt}

Det första närliggande syftet som etableras i elevernas samtal visar att det i undervisningen blir viktigt för eleverna att producera och redovisa ett visst antal frågor för varandra:

Excerpt 1: "Att pumpa tjugo frågor."

1. Axel: Ja, och det var mina frågor. 
2. Theo: Ja, och jag tyckte de var jävligt bra. Det där är bra frågor!

3. Axel: Ja, men jag känner mig ganska nöjd! Jag lyckades pumpa tjugo frågor!

4. Theo: Den här, den här känns lite hög men... ((pekar på en fråga))

5. Axel: ((skratt)) Ja, det kan man ju [ohörbart] säga att det var.

6. Theo: Men du fick fler frågor än vad jag fick.

7. Axel: Det blev lite krystat här på slutet.

8. Theo: Men du fick mer frågor än jag fick. Det är ganska beklagligt.

Att eleverna ska producera många frågor är något som framstår som självklart, det vill säga står fast i samtalet. I samtalet uttrycks det genom att eleverna redovisar och jämför sina egenproducerade frågor med varandra $(\operatorname{rad} 1,3,6)$. I elevernas samtal uppstår dock ett mellanrum om betydelsen av kvaliteten på de frågor som ska produceras ( $\operatorname{rad} 4,7)$. Eleverna försöker helt enkelt att väga kvalitet (rad 4, 5, 7) mot antalet frågor ( $\operatorname{rad} 2,3,6,8)$. Att producera många frågor utgör ett närliggande syfte, dock inte helt utan reflektion från eleverna. En elev beskriver frågorna som formulerats i slutet av uppgiften som "lite krystat" ( $\mathrm{rad} 7)$.

I andra elevsamtal återkommer varianter av det närliggande syftet uttryckt som vilket antal frågor som ska rangordnas, väljas, jämföras eller på något annat sätt bearbetas i grupp. Till exempel uttrycker Viggo i en annan elevgrupp: “Nu, nu kommer det. Rangordna frågorna utifrån undersökningsbarhet och relevans, välj tre frågor. Vi har redan tagit fram tre frågor." I detta samtal blir produktion av "rätt antal" frågor ett närliggande syfte. Sammanfattningsvis innebär detta närliggande syfte att eleverna riktar sin uppmärksamhet mot antalet frågor snarare än frågornas kvalitet.

\section{B. Att bedöma vilka frågor som är mest relevanta}

Det andra närliggande syftet som etableras i elevernas samtal behandlar frågors relevans. Excerptet nedan kommer från när en elevgrupp om två par jämför och värderar sina frågor (QFT, delsteg 4) inom frågeområdet "Honung innehåller antibakteriella ämnen”. I excerptet samtalar Viggos grupp kring vilka frågor de anser mest intressanta:

Excerpt 2: "Vilka frågor tycker vi var mest intressanta?"

1. Viggo: Vilka frågor tyckte vi var mest intressanta?

2. Linnea: Vi hade lite, några som var lite jämna, samma typ.

3. Emil: Den här kan vi stryka. ((stryker i sitt block))

4. Linnea: Någonting med så här... eh...

5. Emil: Vi stryker den här också. Den är lite för B. ((stryker igen i blocket)) 
6. Linnea: Hade ni någonting om så här “medicin-ish”? Att det händer något i kroppen?

7. Viggo: Nej, egentligen inte! Vi, jo, men vi hade typ så här: “ ̈̈r det bra att ha det i te?"

8. Linnea: Ja, just det!

9. Viggo: Men annars var det typ så här: "Hur kan vi på ett naturligt sätt förändra innehållet i honung så att det bättre hjälper oss bättre att... [ohörbart]?

10. Linnea: Ja, just det!

11. Emil: När man har det i varmt vatten så tänkte ni att egenskaperna skulle förändras eller göra verkningar på kroppen?

12. Viggo: Ja, vad är upptagningsförmågan? Vad är skillnaden?

13. Oskar: Jag behöver gå på toa! ((reser sig och lämnar gruppen))

14. Linnea: Ja, det är väl lite samma som, lite samma som det här med halsgrejen typ?

15. Emil: Den, den gillar jag. ((pekar på en fråga))

16. Linnea: Vi skulle kunna ta något sånt. Ja?

17. Viggo: Det var en fråga. Nu ska vi bara välja två till.

18. Emil: Jag kan tänka mig en om immunförsvaret.

19. Viggo: Immunförsvaret den har vi också på ((pekar på listan med frågor))! Eller resistens.

20. Emil: Ja!

21. Linnea: Ja!

22. Emil: Den är ju ganska intressant!

23. Viggo: Resistens eller immunförsvaret?

Elevernas samtal handlar om vilka frågor som är intressanta ( $\operatorname{rad} 1,22)$. I det här samtalet tolkar vi "intressant" som en fråga om relevans. Att frågorna ska vara intressanta är något som står fast för eleverna. Några frågor anses inte intressanta till exempel är de "lite för B" $(\operatorname{rad} 3,5)$. En av eleverna, Linnea, föreslår att intressanta frågor skulle kunna vara lite "medicin-ish" och att det ska handla om något i kroppen ( rad 6). Samtalet tar därefter en medicinsk riktning och eleverna börjar fylla mellanrummet med frågor om immunförsvaret och resistens ( $\mathrm{rad} 18-19)$ ). Att medicinska frågor klassas som intressanta blir något nytt som står fast i elevernas samtal.

Det närliggande syftet om relevans innehåller i andra elevsamtal även diskussioner om angelägenhet, samhälleliga eller naturvetenskapliga aspekter, undersökningens konsekvenser, huruvida frågorna skiljer sig eller liknar varandra men även utifrån icke-mänskliga aspekter, och uppvisar därmed en bredd av olika aspekter.

\section{Att kategorisera frågor}

I elevernas arbete med att välja några frågor att bearbeta och förbättra etablerades ett 
tredje närliggande syfte om kategorisering av frågor. I excerptet nedan återvänder vi till det första elevparet, Axel och Theo, när de arbetar med att kategorisera de frågor som de skrivit (QFT, delsteg 3) till frågeområdet "Ipren och Alvedon har olika maxdosering per dygn":

\section{Excerpt 3: "Först kategorisera frågorna..."}

1. Theo: Förbättra?

2. Axel: Först kategorisera frågorna.

3. Theo: Well jag, mina går...

4. Axel: Mina är redan ganska...

5. Theo: ... kategoriserade! Det finns så här varför...

6. Axel: Ja, precis!

7. Theo: Det finns varför-frågor och påstående-frågor som är i princip omgjorda till frågor. Alltså påståenden som är omgjorda till frågor och varför liksom.

8. Axel: Ja, här skulle man, framförallt så tänker jag mig att man skulle kunna... de här liksom mer samhällsperspektiv...

9. Theo: Ja, okej. ((gäspar))

10. Axel: Det är verkligen samhällsperspektiv! Vilken är den vanligaste användningen vid överdoseringen? Hur vanligt är det? Vilken är mest populär?

11. Theo: Och sedan har vi PETA-frågor!

12. Axel: Ja, precis. ((skratt)) Sen har vi mera koppling till andra djur, liksom andra levande organismer. Sen har vi lite sådant här hur fungerar det egentligen...

13. Theo: Ja, exakt!

14. Axel: ... hur är de uppbyggda och vad är det de gör i kroppen?

15. Theo: Ja, det finns ju lite många, lite flera så här, vad ska man säga, kemiska frågor i form av beteckning om du förstår vad jag menar. Inte beteckningen men hur funkar det?

16. Axel: Ja, precis!

17. Theo: Sen finns det så här mera "ish"-sociala om du fattar vad jag menar, $\mathrm{i}$ form av att det finns så här yttre och inre. Fattar du vad jag menar? Jag tycker man kan kategorisera det för många av dina frågor är så här "Vad händer?" och sen så är det "Vad egentligen händer i kroppen?"

18. Axel: Ja.

19. Theo: Och det är lite grand det här "Vad händer och varför?” som jag har.

20.Axel: Precis, precis, fast du har mer generellt. Jag har tagit lite mer specifika frågor men egentligen har vi i stort sett samma frågor.

Att eleverna ska kategorisera sina frågor är något som står fast i det här samtalet (rad 2-4). Däremot uppstår ett mellanrum kring utifrån vilka kriterier frågorna ska kategoriseras. En av eleverna väljer att inordna sina frågor i kategorierna "varförfrågor” och "påstående-frågor” (rad 7). Då det uppstår ett mellanrum om vad som menas med dessa kategorier tar samtalet en annan riktning ( $\mathrm{rad} 8)$. I det fortsatta 
samtalet kategoriseras frågorna istället som frågor med samhällsperspektiv ( $\operatorname{rad} 8$, 10) och som "PETA-frågor" ( $\operatorname{rad} 11)$. Här har vi tolkat "peta-frågor" som djurrättsfrågor (PETA är en förkortning av People for the Ethical Treatment of Animals) vilket stöds av att Axel som i sin utsaga skapar en relation mellan "PETA" och "andra djur, liksom andra levande organismer" ( $\operatorname{rad} 12)$. En annan kategorisering som Axel föreslår är "hur fungerar det egentligen?" ( $\mathrm{rad} 12$ ), vilket eleverna vidareutvecklar till vad olika kemikalier gör i kroppen och hur ämnen är kemiskt uppbyggda ( $\operatorname{rad} 14-15)$. Eleverna introducerar slutligen en kategorisering av frågor som sociala ( $r a d ~ 17)$ innan de avslutar jämförelsen.

I andra elevers samtal förekommer andra kategoriseringar. En återkommande kategorisering är i öppna och slutna frågor. I excerpt 4 diskuterar Axel och Theo vidare kring vad som räknas som en öppen eller sluten fråga samt om en öppen fråga är bättre än en sluten fråga (QFT, delsteg 3).

\section{Excerpt 4: "Vad är en öppen och sluten fråga?”}

1. Axel: Okej, ändra en öppen fråga till en sluten fråga och vice versa. ((läser från instruktionen)) Ska vi bara?

2. Theo: Finns öppen? Vad ska man ta?

3. Axel: Okej, vad räknas som en öppen fråga och en sluten fråga?

4. Theo: En öppen fråga är väl mer generell och en sluten fråga är specificerad till ett särfall. Right?

5. Axel: Ja.

6. Theo: Det vi behöver göra till exempel, finns det ett uppenbart bättre? Det är en öppen fråga.

7. Axel: Jag tror att en öppen fråga är typ hur vanligt är det med överdosering? Och en sluten skulle kunna vara: Är det vanligare hos kvinnor än hos män?

8. Theo: Exakt, det är exakt det! Jag är ganska, jag tänker också det.

9. Axel: Jag tycker att det känns ganska, ja.

10. Theo: För det du gör är att du säger okej, är det vanligare med överdosering och sedan går du in på ett särfall.

11. Axel: Ja precis. Och att göra en sluten fråga till en öppen. Har vi några slutna frågor?

12. Theo: Eh, vi har typ inga slutna frågor. Kan växter överdosera är en ganska sluten fråga.

13. Axel: ((skratt))

14. Theo: Ja, men det är ju det för det är samma sak som du sa förut. Right. Att du gick in förut på, okej, nu har vi ett särfall här och det är växter. Kan de överdosera? Då ändrar vi det till: Hur vanligt är det generellt att överdosera? Varför blir de här växterna? Varför har just de här växterna annorlunda nummer om de har det?

15. Axel: Ja, det är inte omöjligt att det är något sånt de menar.

16. Theo: Ja, det är ju i princip bara att vi ändrar den här frågan tillbaka det vi sa förut. Vi ändrar kvinnor, det du sa förut med att kvinnor specifikt överdoserar till generella frågor. 
17. Axel: Ja, precis.

18. Theo: Right!

19. Axel: Ja.

I det fjärde excerptet diskuterar Axel och Theo skillnaden mellan öppna och slutna frågor samt ger exempel på hur frågor kan omformuleras. Att det finns öppna och slutna frågor är något som står fast i elevernas samtal. En öppen fråga formuleras som mer generell medan en sluten fråga formuleras som "specificerad till ett särfall” (rad 4). Eleverna försöker även att beskriva skillnaden mellan öppna respektive slutna frågor genom exempel om överdosering $(\operatorname{rad} 7,10,12,14,16)$. Allteftersom elevernas samtal fortgår uppstår det ett mellanrum om vad som skiljer en öppen från en sluten fråga (rad 3, 6, 11, 12, 16). Eleverna blir mindre och mindre säkra. Trots flera försök att slå fast innebörden av öppna respektive slutna frågor lyckas eleverna inte fylla mellanrummet, utan det dröjer kvar. Eleverna saknar kriterier för att fullt ut kunna genomföra arbetet eftersom vad ett kategoriserande av frågor innebär tagits för givet i instruktionerna till eleverna. Samtidigt öppnar avsaknaden av en entydig definition av öppna och slutna frågor upp för ett utforskande av innebörder.

\section{Att hitta och specificera ett undersökningsobjekt}

I elevernas diskussioner etablerades även ett fjärde närliggande syfte om vad som ska undersökas och hur det kan förstås, det vill säga hur undersökningsobjektet kan specificeras. I excerpt 5 utforskar Theo och Axel tillsammans med Maja och Sixten ett möjligt undervisningsobjekt i relation till frågeområdet "Ipren och Alvedon har olika maxdosering per dygn” (QFT, delsteg 4).

Excerpt 5: "Man skulle vilja hitta och specificera någon specifik långvarig konsekvens."

1. Maja: Vad har regelbunden behandling med Ipren respektive Alvedon för långvariga konsekvenser?

2. Axel: Mmmm.

3. Maja: Då är alltså kontrollvariabeln det du ser, den oberoende variabeln är tid och den beroende variabeln är effekt och [ohörbart]. Nu inser jag att vad som helst kan hända med kontrollvariabeln.

[...]

4. Axel: Läs den ((frågan)) igen lite långsammare.

5. Maja: "Vad har regelbunden behandling med Ipren respektive Alvedon för långvariga konsekvenser?"

6. Theo: [ohörbart] 
7. Axel: Man skulle definitivt vilja specificera det rekommenderade intaget och dessutom...

8. Sixten: Kanske långvarigt och hur långvarigt...

9. Axel: Man skulle vilja hitta och specificera någon specifik långvarig konsekvens.

10. Sixten: Men det är det som är frågan: Vad är en långvarig konsekvens?

11. Axel: Ja, precis men man skulle vilja har någonting snarare, vad har det här, vad har det för långvarig påverkan på typ det här enzymet i hjärnan.

12. Theo: Exakt!

13. Maja: Ja, men faktiskt.

14. Theo: Vad finns det för generella [ohörbart].

15. Axel: Ja, snarare än öppet alltså. Vad finns det för långvariga effekter? Hur påverkar det just det här?

16. Theo: Ja.

17. Maja: Okej, vad kan man tänka sig för typ av konsekvens? Smärtgräns?

18. Axel: Ja.

19. Maja: Smärttröskel?

20. Axel: Någon form av typ beroende.

21. Maja: Ja, metabolism alltså vi ska ha mätdata-tänk.

22. Theo: [ohörbart] ... vi har dålig uppfattning om vad som är smärtgräns.

23. Axel: Ja, men det bygger på vad är det egentligen de olika ämnena gör i kroppen och hur påverkar då vad ...

24. Theo: Om du tar en varje gång du får lite huvudvärk så får du ta den varje gång ...

25. Sixten: Men sen så är det ju också så att nu så undersöker vi ju konsekvenser till att vilja höja smärttröskel för att se vad som påverkar. Det är ju den saken som förändrar sig.

26. Axel: Ja, det är ju inte omöjligt att en långvarig medicinering av det skulle liksom...

27. Maja: Höja va? Nej?

28. Axel: Jo, det borde höja smärtgränsen. Nerverna borde domna av typ.

29. Maja: Man vänjer sig.

((Maja och Theo pratar i munnen på varandra.))

30. Maja: Smärttröskeln vi tar det då.

31. Axel: Ja, men det är lite intressant!

Att ett regelbundet intag av värktabletter kan få långvariga konsekvenser för användaren är något som står fast i elevernas samtal (rad 1). Det uppstår trots detta ett mellanrum om vad som menas med långvarighet och konsekvens (rad 9-10) och hur detta ska kunna undersökas ( $\operatorname{rad} 11-13,23$ ). Eleverna försöker att fylla mellanrummet om vad som ska undersökas utifrån termer om mätbarhet. Termer som smärttröskel/smärtgräns ( $\operatorname{rad} 17,19,22,25,28,30)$, beroende ( $\operatorname{rad} 20)$ och

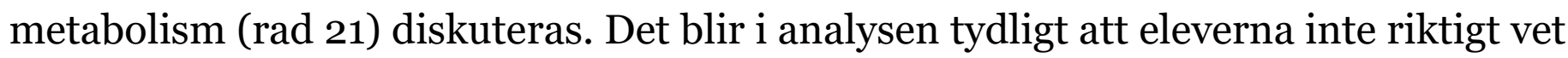
hur de ska kunna undersöka konsekvenserna från långvarig användning av smärtstillande preparat. Mellanrummet dröjer alltså kvar trots att eleverna själva väljer smärtgräns som ett undersökningsobjekt. 


\section{E. Att planera för att genomföra en undersökning}

Det femte och sista närliggande syftet handlar om hur en undersökning skulle kunna genomföras utifrån de frågor som eleverna formulerat. I excerptet fortsätter vi att följa Maja, Sixten, Theo och Axel när de försöker att skissera en tänkt undersökning som svarar mot frågeområdet "Ipren och Alvedon har olika maxdosering per dygn".

Excerpt 6: "Jobbigt att testa själv!”

1. Maja: Ska vi svara på alla eller ska vi välja en?

2. Axel: Ingen aning.

3. Theo: Vi kör en.

4. Axel: Vi börjar med en och vilken börjar vi med?

5. Maja: Vad har en behandling med rekommenderad daglig dos i tre månader med Alvedon respektive Ipren för långvariga konsekvenser för smärttröskel? Man skulle ju...

6. Axel: Den blir jobbigt att testa själv!

7. Maja: Ja.

8. Sixten: Ja, som den är nu.

9. Axel: Då skulle man snarare vilja gå in teoretiskt.

10. Maja: Alltså litteraturstudie?

11. Axel: Snarare teoretiskt vad är det de gör i hjärnan och vad är det de egentligen gör i kroppen? Och gå vidare på: Vad är det som påverkar smärttröskeln och vad finns det för samband mellan de två?

12. Maja: Så då är det teori? Vad är smärttröskeln?

13. Axel: Den är ju ganska svåra att testa. Det krävs en långvarig studie.

I excerpt 6 jämför eleverna de båda kemiska preparaten Ipren och Alvedon. Att en långvarig användning av smärtstillande preparat kan få konsekvenser är något som står fast för eleverna. Det uppstår dock ett mellanrum om hur en undersökning av dessa konsekvenser skulle kunna genomföras ( $\operatorname{rad} 6,8)$. Eleverna försöker att fylla mellanrummet om undersökningsupplägget med förslag om en teoretisk studie (rad 9, 10). Enligt eleverna skulle en teoretisk studie kunna reda ut hur de smärtstillande preparaten arbetar för att sänka individens smärttröskel (rad 11). Eleverna lyckas dock inte reda ut hur en empirisk undersökning i ämnet skulle kunna gå till, vilket leder till att mellanrummet dröjer kvar ( $\operatorname{rad} 13)$.

I excerpt 7 fortsätter eleverna att diskutera hur effekten av de smärtstillande preparaten Alvedon och Ipren kan mätas:

Excerpt 7: "Att kunna mäta effekten."

1. Axel: Det första man vill kolla på i så fall på den frågan är ju: Vad är det för ämnen som är verksamma? 
2. Maja: Vi har ju redan [ohörbart].

3. Axel: Ja, men precis, men... ja, ja, det... då skulle man behöva kolla på vad är det...

4. Maja: Det skulle man faktiskt kunna göra!

5. Axel: Man skulle kunna kolla vad är det som plockar upp det? Vad har det ämnet för kapacitet? Om det ämnet som plockar upp det där är ett ämne som är ganska likt dem så kan man ju gissa. Det skulle också kunna rinna igenom. Så det är också ganska...

6. Maja: [ohörbart]

7. Axel: Ja, ja.

8. Maja: Men då måste man kunna mäta effekten av det liksom?

9. Axel: Ja, eventuellt så skulle man kunna göra någon form av typ titrering på något vänster för att testa.

10. Maja: Okej, man tar reda på ämnet genom att man titrerar?

11. Axel: Det är ju det! Om du tänker dig att du har det här ämnet upplöst i vatten och du har ämnet som plockar upp det upplöst i vatten. Testa att dränka en [ohörbart, Axel blir avbruten av Maja som ställer en ohörbar fråga]. Ja, i och för sig. Men fortfarande, man skulle kunna göra en faktisk studie på det. Förmodligen.

12. Maja: Ja, men du, det är fan inte så jävla dumt! Sen så skulle man skulle ju kunna testa det, [ohörbart] typ när, var i sin metabolismcykel man är.

13. Axel: Ja.

14. Maja: Och om man har andra saker på sig.

15. Axel: Ja, förmodligen finns det andra hormoner och skit som påverkar. Men det făr man ju då väga in i diskussionen.

16. Theo: Exakt!

Den första delen av excerptet innefattar en specificering av undersökningsobjektet genom en diskussion om vilka ämnen som är verksamma i Ipren och Alvedon (rad 15). Maja föreslår då att en undersökning måste vara mätbar ( $\operatorname{rad} 8)$. Undersökningars mätbarhet är något som står fast för eleverna. Däremot skapas ett mellanrum om hur effekten av de smärtstillande preparaten Alvedon och Ipren kan mätas. Eleverna försöker att fylla mellanrummet genom att föreslå metoden titrering då värktabletter kan lösas i vatten ( $r a d$ 9-11). I det fortsatta samtalet uppstår ett nytt mellanrum om titreringens applicerbarhet/generaliserbarhet på en verklig kropp (12-15). Eleverna försöker att fylla det nya mellanrummet genom att lyfta de hormonella och metaboliska processer som kan inverka på en undersökning ( $\operatorname{rad} 12,15)$.

\section{Diskussion}

Resultaten visar att fem närliggande syften etablerades under elevernas arbete med QFT: (A) att producera så många frågor som möjligt, (B) att bedöma vilka frågor som är mest relevanta, (C) att kategorisera frågor, (D) att hitta och specificera ett undersökningsobjekt och (E) att planera för att genomföra en undersökning. Flera av 
de närliggande syften som identifierades i elevernas samtal väcker frågor om hur lärarnas instruktioner och arbetsgången för QFT tolkades ur ett elevperspektiv. Innan vi fördjupar oss i analysen av elevernas arbete så vill vi betona att både de instruktioner som eleverna fick och de modifieringar som gjordes av QFT var ett resultat av det gemensamma arbetet i forskningsgruppen. Det vill säga den kritiska blicken och analysen gäller både forskningsgruppens egna planeringsarbete och hur instruktionerna togs emot av eleverna.

\section{Kontinuitet mellan närliggande och övergripande syften}

Enligt Johansson och Wickman (2011) synliggörs lärandeprogression genom att det närliggande och övergripande syftet är kontinuerligt med varandra. De närliggande syften som etablerades i elevernas samtal stämmer i huvudsak överens med de olika stegen i QFT. Vi kan se detta som ett uttryck för att den genomförda undervisningen faktiskt strukturerades utifrån QFT samt att eleverna ansträngde sig att följa lärarnas instruktioner och de deluppgifter som de fått.

Det första närliggande syftet om "att producera så många frågor som möjligt" överensstämmer med QFT, delsteg 2. Delsteget innebar att eleverna skulle producera många frågor utan att värdera eller reflektera närmare över frågornas kvalitet i relation till undersökningsbarhet. Det visade sig att eleverna tog uppgiften om att producera en stor mängd frågor på största allvar, något som kom att påverka deras fortsatta arbete. Då huvudfokuset låg på antalet frågor, snarare än att frågorna skulle vara undersökningsbara skapades en inbyggd svårighet $\mathrm{i}$ att senare förbättra dem. Att inte frågornas kvalitet betonas i instruktionen för QFT ser vi som en begränsning, då det i vår studie innebar att frågan om undersökningsbarhet inte sattes i förgrunden av eleverna.

De närliggande syftena om "att bedöma vilka frågor som är mest relevanta" och "att kategorisera frågor" kan även de relateras till delsteg och instruktioner för QFT. Enligt delsteg 3 och 4 skulle eleverna förbättra sina frågor genom att bland annat kategorisera dem och fundera på skillnaden mellan öppna och slutna frågor. Eleverna skulle även rangordna frågorna utifrån relevans. Vad som menas med kategorisering eller relevans är dock inte något som förklaras närmare i lärarnas instruktioner. Det visade sig ge upphov till en hel del förvirring bland eleverna. Som vi tidigare sett exempel på så famlar eleverna i kategoriseringen av frågorna och väljer att dela in dem i kategorier som "varför-frågor", "påstående-frågor", "peta-frågor", "hur fungerar det egentligen?" eller "frågor med samhällsperspektiv”. Eleverna 
återkommer i samtalen också till distinktionen öppna och slutna frågor. Distinktionen introducerades av den undervisande läraren i inledningen av lektionen men innebörderna av den utvecklades inte. Eleverna förutsattes veta skillnaden. I samtalen framstår eleverna som väl införstådda i att frågor kan ses som öppna eller slutna. Att kategorisera egna redan formulerade frågor var dock lättare sagt än gjort. Det är inte självklart att en mer specificerad instruktion och genomgång av öppna och slutna frågor skulle ha bidragit till en högre grad av kontinuitet mellan det närliggande syftet att kategorisera frågor och det övergripande syftet att utveckla elevernas förmåga att formulera undersökningsbara frågor i naturvetenskap. Detta är något som skulle behöva undersökas vidare. Vad gäller det närliggande syftet om relevans så framgår att eleverna inte riktigt vet hur de ska ta sig an frågan om relevans - de saknar en gemensam förståelse av utifrån vilka kriterier de ska bedöma relevans. Relevans blir istället något som eleverna förhandlar om. I inledningen av elevexcerpt 2 så uttrycker eleverna att frågor som är lite "medicin-ish" ses som relevanta. I elevsamtalen om relevans ingår även diskussioner om angelägenhet, samhälleliga eller naturvetenskapliga aspekter, undersökningens konsekvenser, huruvida frågorna skiljer sig eller liknar varandra men även utifrån icke-mänskliga aspekter. Det närliggande syftet innefattar därmed en bredd av olika aspekter. Sammanfattningsvis visar analysen att de närliggande syftena "att bedöma vilka frågor som är mest relevanta" och "att kategorisera frågor" etableras då eleverna försöker greppa vad relevans och kategorisering innebär. Dessa närliggande syften blir därmed inte direkt kontinuerliga med undervisningens och studiens övergripande syfte att utveckla elevernas förståelse av undersökningsbarhet.

Det närliggande syftet om "att planera för att genomföra en undersökning”, är ett syfte som också är relaterat till lärarnas instruktioner och QFT. I syftet diskuterar eleverna ett praktiskt genomförande av de frågor de formulerat utifrån parametrar som mätbarhet, observationer, laborationsutrustning och metoder, felkällor och litteraturstudier. De samtalar även om olika etiska, samhällsvetenskapliga och miljövetenskapliga aspekter av själva genomförandet av undersökningen. Att designa en undersökning var en uttolkning av QFT:s delsteg 5 där lärare och elever tillsammans skulle bestämma hur de tidigare frågorna ska användas. Att eleverna skulle pröva att designa en undersökning var en anpassning till att lektionen var en introduktion till kursen Gymnasiearbete. Elevernas samtal visar dock att de har svårt att konstruera undersökningar som är genomförbara i en gymnasieskolas laborationssalar utifrån de frågor de formulerat. Deras samtal blir mer som teoretiska 
antaganden om vad som kan tänkas vara möjligt att undersöka. Deras mer eller mindre kvalificerade antaganden kan tänkas både vara en konsekvens av att de tre frågeområdena är för långt ifrån elevernas egna laborativa kunskaper men också en konsekvens av att instruktionerna inte betonat att undersökningarna ska genomföras i en gymnasiekontext. Då det närliggande syftet väcker frågan om undersökningsbarhet så blir detta närliggande syfte kontinuerligt med studiens övergripande syfte.

Det närliggande syftet "att hitta och specificera ett undersökningsobjekt" visar att förhandla, diskutera, värdera och samtala om vad som kan bli intressanta undersökningsobjektet var en viktig del i elevernas arbete med att bearbeta sina frågor. Att förhandla om, diskutera eller värdera undersökningsobjektet, och på så vis forskningsfrågan, var dock inte en i förväg planerad aktivitet och ingår inte i modellen för QFT. Förhandlingen om undersökningsobjektets specificering uppstod istället spontant i elevernas samtal. Det närliggande syftet om specificering av undersökningsobjektet bidrar dock till att skapa kontinuitet med det övergripande syftet att utveckla elevernas förmåga att formulera naturvetenskapligt undersökningsbara frågor. Utan ett arbete med att precisera undersökningsobjektet blir det svårt att formulera naturvetenskapligt undersökningsbara frågor.

\section{QFT som modell för att formulera undersökningsbara frågor i} naturvetenskap

Didaktiska modeller genereras för specifika syften, användare och användningsområden och är därmed sällan generiska (Wickman m.fl., 2018). Didaktiska modeller kan dock prövas i nya undervisningssammanhang genom en så kallad mangling. I den här studien har vi valt att mangla QFT i ett svenskt skolsammanhang och i relation till naturvetenskaplig undervisning med fokus på systematiskt undersökande. Resultaten pekar på att QFT tenderade rikta eleverna mot formuleringar av frågor mer allmänt och till att följa de givna instruktionerna. QFT visade sig dock vara användbar ur forskningssynpunkt i och med att modellen bidrog till att synliggöra en diskrepans mellan våra förväntningar på elevernas förmåga att formulera naturvetenskapliga frågor och deras kunskaper om vad ett naturvetenskapligt frågeformulerande kan innebära. Tidigare forskning om öppna undersökningar pekar också på att det är viktigt att elever ges stöd i genomförandet av öppna undersökningar initialt (Bianchi \& Bell, 2008; Stokhof m.fl., 2019). Mot bakgrund av att förekomsten av öppna undersökningar med möjligheter för elever att 
formulera egna frågeställningar är mycket begränsade i svensk skola (Lunde m.fl., 2015) blir vår slutsats att detta är något som den naturvetenskapliga undervisningen behöver adressera oftare och återkommande.

För att QFT ska kunna fungera som en utgångspunkt för att utveckla elevers förmåga att formulera naturvetenskapligt undersökningsbara frågor behöver dock läraren handleda eleverna i diskussioner om fördelar- och nackdelar med respektive frågetyp samt bidra med redskap för att värdera och specificera frågor. Distinktionen öppna-slutna frågor som användes i undervisningen visade sig inte fungera som redskap för specificering. Eleverna kunde använda distinktionen för att klassificera frågor som de formulerat men inte för att utveckla frågorna så att de blev mer undersökningsbara. Däremot bidrog avsaknaden av en entydig definition till att eleverna riktade sin uppmärksamhet mot vad som kännetecknar de två frågetyperna. En tänkbar utveckling av modellen skulle kunna vara att introducera begreppsliga redskap som ligger närmare utformningen av naturvetenskapliga undersökningar och avsätta tid för gemensam uppföljning där olika frågetyper kan jämföras. En möjlighet skulle kunna vara att pröva fruktbarheten i att använda exempelvis Schwabs (1978) begrepp för olika kunskapsintressen inom naturvetenskap: taxonomiskt intresse (att beskriva, sortera, benämna), sambandsintresse (att förutsäga nya observationer ur redan gjorda observationer) och förklaringsintresse (att förklara varför något observeras). Eleverna skulle kunna få i uppgift att kategorisera sina frågor med hjälp av kunskapsintressen, men också få pröva att omformulera frågor från ett kunskapsintresse till ett annat.

Vår studie indikerar även att en växelverkan mellan teori och praktik, det vill säga ett frågeformulerande i kombination med ett laborativt undersökande hade varit gynnsamt för att utveckla förmågan att formulera naturvetenskapligt undersökningsbara frågor. I en artikel från 2017, publicerad efter att vi genomfört vår studie, betonar Minigan och Beer (2017) vikten av att frågeområdet fångar elevernas uppmärksamhet och att det stimulerar själva frågeformulerandet. Att hitta ett intressant frågeområde kan enligt Minigan \& Beer (2017) vara en av de största utmaningarna med metoden. Vår analys av elevernas samtal visar att de frågeområden som vi formulerat utgjorde en begränsning för elevernas arbete med att formulera frågor. En möjlig tolkning är att eleverna hade för liten teoretisk och laborativ kunskap om de olika frågeområdena för att kunna formulera kvalitativa frågor och designa genomförbara undersökningar. En annan möjlig tolkning är att eleverna saknade förmåga att knyta an till tidigare erfarenheter av systematiskt 
undersökande i naturvetenskapliga ämnen. För att stötta eleverna skulle läraren kunna lägga mer vikt vid det kollektiva samtalet i undervisningen. På så sätt skulle en kontinuitet mellan tidigare undervisningssammanhang och det pågående arbetet med formulering och bearbetning av undersökningsbara frågor kunna skapas (jfr Andrée, Wickman \& Lager-Nyqvist, 2017). Stokhofs m.fl. (2019) forskning kring användning av tankekartor för formulering av frågor stödjer den senare tolkningen. De visade att lärare genom att etablera ett delat ansvar och kollektivt ägarskap för arbetet med tankekartor i klassrummet kunde involvera eleverna i ett mer intensivt kollektivt kunskapsbyggande. På motsvarande sätt är det möjligt att förberedande, eller mer omfattande, inslag i undervisningen av kollektiv formulering och bearbetning av frågor kan skapa bättre förutsättningar för utveckling av elevernas förmåga att formulera undersökningsbara frågor.

En slutsats är att QFT som modell är för generell för att fungera i naturvetenskaplig undervisning och att undervisningen måste planeras i närmare växelverkan mellan styrdokument, lärarens ämneskompetens och elevgruppens behov. Denna slutsats ligger i linje med Minigan och Beers (2017) slutsats att även om QFT presenteras som en steg för steg-process så finns det fortfarande utrymme för läraren att skräddarsy och förändra metoden utifrån sin kunskap om de aktuella eleverna samt egna insikter om vilka praktiker som bäst passar det egna klassrummet. QFT bör snarare tillskrivas ett dynamiskt förhållningssätt än ses som en statisk strategi. Efter vår egen mangling av QFT kan vi inte annat än hålla med Minigan och Beer (2017) i att QFT behöver tillskrivas ett dynamiskt förhållningssätt och anpassas till rådande undervisningskontext.

\section{Behov av fortsatt mangling}

Om QFT ska kunna bli användbar som didaktisk modell för undervisning rörande formulering av undersökningsbara frågor i naturvetenskap krävs fortsatt mangling av QFT utifrån såväl tidigare forskning om undersökande arbete i naturvetenskap och naturvetenskapens karaktär som undervisning i naturvetenskap inom andra ämnesområden och sammanhang.

Ett motiv för genomförandet av den här studien var att pröva QFT som didaktisk modell för att utveckla undervisning med fokus på formulering av naturvetenskapligt undersökningsbara frågor. Bakgrunden till detta var problematiken med att eleverna själva sällan får möjlighet att träna förmågan att formulera undersökningsbara frågor utifrån en övergripande forskningsfråga eller problemsituation (Lunde m.fl., 2015; 
Rothstein \& Santana, 2011). Flera av de närliggande syften som etablerades i elevernas samtal visar också på en ovana hos eleverna att formulera egna undersökningsbara frågor. En tolkning är att denna ovana kan förstås i sken av en avsaknad av explicit undervisning om formulering av undersökningsbara frågor i naturvetenskap (jfr Lunde m.fl., 2015; Stokhof m.fl., 2019). Ytterligare en möjlighet är att eleverna, i likhet med de elever som fick göra öppna undersökningar i Wolf och Frasers (2008) studie, behövde mer stöd och vägledning från lärare i början för att kunna bli alltmer självständiga efterhand.

I parallell med Ledermans (2007) argument om att utveckling av elevers förståelse för naturvetenskapens karaktär (nature of science) kräver undervisning som explicit behandlar dessa frågor, så kräver också utveckling av elevers förmåga att formulera naturvetenskapligt undersökningsbara frågor en undervisning som explicit fokuserar frågeformulering. Resultaten från den här studien pekar också på nödvändigheten av att situera arbetet med formulering av frågor i en naturvetenskaplig kontext där eleverna får möjlighet att uppmärksamma olika kvaliteter av undersökningsbarhet inom olika naturvetenskapliga ämnesområden.

Våra resultat ger exempel på hur eleverna försöker reda i vad som kan utgöra ett undersökningsobjekt: Vad kan det innebära "att hitta och specificera ett undersökningsobjekt"? Eleverna bearbetning av undersökningsobjektet tenderar dock bli abstrakt vilket kan förstås i skenet av att de givna frågeområdena kan ha varit alltför generella och långt ifrån elevernas erfarenheter. Vi har i en tidigare studie (Björnhammer m.fl., 2020) visat på behovet av att skapa möjligheter för elever att aktivt arbeta med att precisera eller specificera själva undersökningsobjektet, det vill säga att låta eleverna arbeta med frågan om vad de avser att undersöka. I den tidigare studien identifierade vi även att elevers förmåga att formulera undersökningsbara frågor i naturvetenskap innefattar en dimension av operationalisering av undersökningsobjektet. Också den här studien understryker behovet av att arbeta med hur frågor kan göras undersökningsbara. Vi menar även att vidare forskning behövs för att studera hur detta kan genomföras: i vilken utsträckning formulering av undersökningsbara frågor bör eller måste utgöra del av en undersökningspraktik, vilken betydelse elevernas tidigare erfarenheter av undersökningsmetoder och kunskaper om det ämnesområde som ska undersökas har, samt betydelsen av begreppsliga redskap för att göra frågan om centrala aspekter av undersökningsbarhet explicita (jfr Lederman, 2007 om nödvändigheten av att 
hantera frågor om naturvetenskapens karaktär som ett explicit innehåll i undervisningen).

\section{Överförbarhet och begränsningar}

I den här studien har QFT manglats som didaktisk modell i ett svenskt skolsammanhang och i relation till naturvetenskaplig undervisning med fokus på systematiskt undersökande. I detta arbete tolkades och omsattes QFT till undervisning i ett specifikt sammanhang. Undervisningen planerades för en specifik grupp elever vid en viss tidpunkt och på en viss plats av en särskild grupp forskande lärare med intresse för såväl den specifika undervisningssituationen som för hur den planerade och genomförda undervisningen kan ta fram ny kunskap om undervisning. En grundläggande fråga att ställa - givet studiens utgångspunkt i och intresse för det partikulära sammanhanget - är vilka möjligheter som finns att ta fram resultat som blir generaliserbara och överförbara till andra sammanhang.

Larsson (2009) argumenterar för en pluralistisk förståelse för generaliserbarhet i kvalitativ forskning som innebär tre olika sätt att resonera: (I) skapa förutsättningar för generalisering genom att maximera variation, (II) generalisering genom kontextlikhet och (III) generalisering genom mönster-igenkänning. I den här studien har förutsättningar för generalisering genom variation framförallt skapats genom att analysen designades för att fånga den variation som uppstår i undervisningen avseende vilka närliggande syften som etableras i de deltagande elevgrupperna. Genom att synliggöra den bredd av variation som uppstår i undervisningen skapas rikare möjligheter till generaliserbarhet. Variationen är dock begränsad till de specifika klasser, elever och lärare som ingår i studien.

Det andra alternativet till generalisering, generalisering genom kontextlikhet, synliggör vissa begränsningar avseende möjligheterna att generalisera resultaten. Studien är empiriskt begränsad till kursen Gymnasiearbete vid naturvetenskapligt program. Detta innebär att de elever som deltar i studien går sista året av tre på naturvetenskapligt program och har därmed merparten av de naturvetenskapliga studierna i gymnasieskolan bakom sig. Studien är också begränsad till en skola i stockholmsregionen med resursstarka elever (sett till meritvärden för antagning till årskurs 1 och bakgrundsfaktorer i form av föräldrarnas genomsnittliga utbildningsnivå och andel nyinvandrade elever jämfört med övriga skolor i Sverige). Sammantaget innebär de empiriska förutsättningarna att QFT har prövats i ett sammanhang med mycket kunniga elever i slutet av sina gymnasiestudier. Det är 
rimligt att anta att elever i gymnasieskolans tidigare årskurser eller grundskolan kan etablera andra närliggande syften än de som etablerades i denna studie. Vi skulle exempelvis kunna förvänta oss att elever i andra sammanhang i mindre grad utgår från kvaliteter avseende frågors undersökningsbarhet eller att de synliggör andra dimensioner av relevans och genomförbarhet.

Avseende generalisering genom mönsterigenkänning innebär detta att en del av ansvaret för att pröva resultatens generaliserbarhet förläggs till läsaren. Det handlar om att den lärare som tar del av resultaten behöver pröva i vilka avseenden de närliggande syften som identifierats i studien fungerar som sätt att beskriva och tolka utmaningar som uppstår i undervisning som syftar till att utveckla elevers förmåga att formulera och bearbeta undersökningsbara frågor i nya sammanhang. I avsnitten "QFT som modell för att formulera undersökningsbara frågor i naturvetenskap" och "Behov av fortsatt mangling" pekar vi på några av de resultat som vi ser har tydligast bäring på naturvetenskaplig undervisning i andra sammanhang. I viss mån kan möjligheterna att generalisera resultaten också anses ha prövats gentemot nya sammanhang mot bakgrund av att alla lärare som deltagit i forskargruppen representerar erfarenheter från skolor med olika förutsättningar från såväl gymnasiet som högstadiet.

\section{Referenser}

Abrahams, I., \& Millar, R. (2008). Does practical work really work? A study of the effectiveness of practical work as a teaching and learning method in school science. International Journal of Science Education, 30(14), 1945-1969. https://doi.org/10.1080/09500690701749305

Andrée, M. (2012). Altering conditions for student participation and motive development in school science: learning from Helena's mistake. Cultural Studies of Science Education, 7(2), 425438. https://doi.org/10.1007/s11422-011-9314-X

Andrée, M., \& Lager-Nyqvist, L. (2012). 'What do you know about fat?' Drawing on diverse funds of knowledge in inquiry based science education. Nordic Studies in Science Education, 8(2), 178-193. https://doi.org/10.5617/nordina.526

Andrée, M., Wickman, P-O., \& Lager-Nyqvist, L. (2017). Remembering as instructional work in the science classroom. I R. Säljö, P. Linell, \& Å. Mäkitalo, (Red.), Memory practices and learning: experiential, institutional, and sociocultural perspectives. (Book series: Advances in cultural psychology: constructing human development), (s. 75-92). IAP.

Bianchi, H., \& Bell, R. (2008). The many levels of inquiry. Science and Children, 46(2), 26-29.

Bielik, T., \& Yarden, A. (2016). Promoting the asking of research questions in a high-school biotechnology inquiry-oriented program. International Journal of STEM Education, 3(15), 1-13. https://doi.org/10.1186/s40594-016-0048-x

Björnhammer, S., Andrée, M., Nordling, J. Dudas, C., Freerks, P., Jahdadic, S., Lundström, J. Lavett Lagerström, M., da Luz, J., Planting-Bergloo, S., Puck, S., Reimark, J., Wennerström, 
P., Westman, F., \& Wiblom, J. (2020). Vad kan elever som kan formulera naturvetenskapligt undersökningsbara frågor? Forskning om undervisning och lärande, 8(1), 81-104.

Chaiklin, S. (1999). Developmental teaching in upper-secondary school. I M. Hedegaard \& J. Lompscher (Red.), Learning activity and development (s. 187-210). Aarhus University Press.

Clark, S., Harbaugh, A.G., \& Seider, S. (2019). Fostering adolescent curiosity through a question brainstorming intervention. Journal of Adolescence, 75, 98-112.

http://dx.doi.org/10.1016/j.adolescence.2019.07.007

Dewey J. (1938/2015). Erfarenhet och utbildning. I S. Hartman, U. P. Lundgren \& R. M. Hartman (Red.), Individ, skola och samhälle: utbildningsfilosofiska texter (s. 163-219). Natur \& Kultur.

The Design-Based Research Collective. (2003). Design-based research: An emerging paradigm for educational inquiry. Educational Researcher, 32(1), 5-8.

http://dx.doi.org/10.3102/0013189X032001005

Dudas, C., Rundgren, C-J., \& Lundegård, I. (2018). Didaktisk modellering av komplexa hållbarhetsfrågor i gymnasiets kemiundervisning. Nordic Studies in Science Education, 14(3), 267-284. https://doi.org/10.5617/nordina.5871

Eriksson, C., Lavett-Lagerström, M., \& Andrée, M. (2018). Utmaningar i bedömning av elevers förmåga att planera systematiska undersökningar: kritisk granskning av ett diagnostiskt stödmaterial för bedömning i NO åk 1-6. Forskning om undervisning \& lärande, 6(1), 6-22.

Gyllenpalm, J. (2010). Teachers' language of inquiry: the conflation between methods of teaching and scientific inquiry in science education. (Doktorsavhandling). Stockholms universitet.

Gyllenpalm, J., Wickman, P-O., \& Holmgren, S-O. (2010). Teachers' language on scientific inquiry: Methods of teaching or methods of inquiry? International Journal of Science Education, 32(9), 1151-1172. https://doi.org/10.1080/09500690902977457

Hodson, D. (1996). Laboratory work as scientific method: three decades of confusion and distortion. Journal of Curriculum Studies, 28(2), 115-135.

https://doi.org/10.1080/0022027980280201

Hodson, D. (2014). Learning science, learning about science, doing science: different goals demand different learning methods. International Journal of Science Education, 36(15), 2534-2553. https://doi.org/10.1080/09500693.2014.899722

Hofstein, V. N., \& Lunetta, A. (2004). The Laboratory in Science Education: foundations for the Twenty-First Century. Science Education, 88(1), 28-54.

http://dx.doi.org/10.1002/sce.10106

Högström, P., Ottander, C., \& Benckert, S. (2012). Lärares mål med laborativt arbete: utveckla förståelse och intresse. Nordic Studies in Science Education, 2(3), 54-66.

Johansson, A.-M., \& Wickman, P-O. (2011). A pragmatist approach to learning progressions. I B. Hudson \& M. A. Meyer (Red.), Beyond fragmentation: didactics, learning, and teaching (s. 47-59). Barbara Budrich Publishers.

Kelly, G.J., \& Cunningham, C.M. (2019). Epistemic tools in engineering design for K-12 education. Science Education, 103(4), 1080-1111. https://doi.org/10.1002/sce.21513

Larsson, S. (2008). A pluralist view of generalization in qualitative research. International Journal of Research \& Method in Education, 32(1), 25-38.

https://doi.org/10.1080/17437270902759931

Lederman, N.G. (2007). "Nature of science: Past, present and future". I S.K. Abell \& N.G. Lederman (Red.), Handbook of research on science education (s. 831-880). London: Routledge. 
Lunde, T., Rundgren, C-J., \& Chang Rundgren, S-N. (2015). När läroplan och tradition möts - hur högstadielärare bemöter yttre förväntningar på undersökande arbete i

naturämnesundervisningen. Nordic Studies in Science Education, 11(1), 88-101.

https://doi.org/10.5617/nordina.783

Lunde, T., \& Sjöström, J. (2020). Didaktiska modeller som kärnan i ämnesdidaktik: forskning som eftersträvar en professionsvetenskap för lärare. ATHENA Didaktik.

https://doi.org/10.3384/atena.2020.3299

McKenney, S., \& Reeves, T. (2012). Conducting educational design research. Routledge.

Minigan, A. P., \& Beer, J. (2017). Inquiring minds: using the question formulation technique to activate student curiosity. The New England Journal of History, 74(1), 114-136.

Minigan, A., Westbrook, S., Rothstein, D., \& Santana, L. (2017). Stimulating and sustaining inquiry with students' questions. Social Education, 81(5), 268-272.

Rothstein, D., \& Santana, L. (2011). Teaching students to ask their own questions. One small change can yield big results. Harvard Education Letter, 27(5), 1-2.

Rothstein, D., Santana, L., \& Minigan A. P. (2011). Making questions flow. The question formulation technique helps students move from passive receivers of information to active seekers of knowledge. Question for Learning, 73(1), 70-75.

Schwab, J. J. (1978). Science, curriculum and liberal education: selected essays. Chicago University Press.

Seifeddine Ehdwall, D., \& Wickman, P-O. (2018). Hur lärare kan stödja andraspråkselever på gymnasiet att tala kemi. Nordic Studies in Science Education, 14(3), 299-316.

https://doi.org/10.5617/nordina.5870

Skolforskningsinstitutet (2020). Laborationer i naturvetenskapsundervisningen. Systematisk översikt 2020:01. Skolforskningsinstitutet.

Skolverket (2011b), Mål för gymnasiearbetet, https://www.skolverket.se/undervisning/gymnasieskolan/laroplan-program-och-amnen-igymnasieskolan/gymnasieprogrammen/program?url=1530314731\%2Fsyllabuscw\%2Fjsp\%2 Fprogram.htm\%3FprogramCode\%3DNA001\%26tos\%3Dgy\%26p\%3Dp\&sv.url=12.5dfee4471 5d35a5cdfa9295\#anchor 1 (hämtad 2021-04-16)

Skolverket (2011a), Kemi, fysik och biologi ämnets syfte, https://www.skolverket.se/undervisning/gymnasieskolan/laroplan-program-och-amnen-igymnasieskolan/gymnasieprogrammen/amne?url=1530314731\%2Fsyllabuscw\%2Fjsp\%2Fsu bject.htm\%.3FsubjectCode\%.3DKEM\%26tos\%3Dgy\&sv.url=12.5dfee44715d.35a.5cdfa92a.3\#an chor2 (hämtad 2021-04-16)

Stokhof, H., de Vries, B., Bastiaens, T., \& Martens, R. (2019). Mind map our way into effective student questioning: a principle-based scenario. Research in Science Education, 49, 347369. https://doi.org/10.1007/s11165-017-9625-3

Wickman, P-O. (2006). Aesthetic experience in science education. Learning and meaning-making as situated talk and action. Routledge.

Wickman, P-O. (2014). En pragmatisk didaktik. I B. Jakobson, I. Lundegård \& P-O. Wickman (Red.), Lärande i handling. En pragmatisk didaktik (s. 17-24). Studentlitteratur.

Wickman, P-O., Hamza, K., \& Lundegård, I. (2018). Didaktik och didaktiska modeller för undervisning i naturvetenskapliga ämnen. Nordic Studies in Science Education, 14(3), 239249. https://doi.org/10.5617/nordina.6148

Wolf, S. J., \& Fraser, B. J. (2008). Learning environment, attitudes and achievement among middle-school science students using inquiry-based laboratory activities, Research in Science Education, 38(3), 321-341. https://doi.org/10.1007/s11165-007-9052-y 